\title{
The Belt and Road: Improving Education, Welfare and Growth of Member Countries
}

\author{
Isaque Manteiga Joaquim \\ UEM- Faculty of Economics -Mozambique \\ School of Economics - Shandong University, \\ Jinan City, P.R. China \\ *Corresponding author
}

\author{
Shah Zaman \\ School of Economics \\ Shandong University \\ Jinan City, P.R. China
}

\begin{abstract}
The Silk Road Economic Belt routes covers more than 60 countries and regions accounting for 30 per cent of Global GDP and world's merchandise up to 35 per cent. By 2050, SREB routes aims to contribute 80 per cent of Global GDP growth and will advances three billion more people into middle class from Asia to Europe via Southe ast Asia, Central Asia, West Asia and the Middle East. Asian countries vary in size and complexity having more than sixty per cent consumers of the world market but are not integrated yet, while European Union is extremely integrated market with more than 500 million consumers. Basic idea behind the research is that whether EU trading bloc has improved the performance of member countries or not (regarding education, welfare \& growth)? Findings shows that the EU have improved the performance of member countries and all they are moving in same like situation of band. On the other hand, Asian countries are behaving in some irrespective manner. Now, it is suggestion for Asian countries to make trading and economic blocs for improved performance of member countries and better wellbeing of the people in near future and SREB will plays a main role.
\end{abstract}

Keywords-Belt and Road, Trading Bloc, Asian Countries, European Union, Pakistan, China

\section{INTRODUCTION}

More than 2,000 years ago, China's imperial envoy Zhang Qian established Silk Road a trade to link China to Central Asia and the Arab world as Silk Road name comes from China's most important exports silk. Belt and Road initiative is a blue print for world development in new world order and offers a modern day solutions that fosters growth and development in $21^{\text {st }}$ century. The Belt and Road refers land based Silk Road Economic Belt, which covers more than 60 countries and regions accounting for 30 percent of global GDP and world's merchandise up to 35 percent. By 2050, SREB routes aims to contribute 80 percent of global GDP growth and will advances three billion more people into middle class from Asia to Europe via Southeast Asia, Central Asia, West Asia and The Middle East.

According to ILO Population report in 2010, five countries of Asia region China, India, Indonesia, Pakistan and Bangladesh are from seven most populous countries of the world. The nature, size and structure of Asia region have been changing qualitatively and quantitatively. Despite obstacles like corruption, fiscal deficit and regional conflicts Asia attained impressive growth in last decade which was mainly due to economic reforms but these are not enough. While European Union achieved a well-built position with one voice are 28 member countries from Central and Eastern Europe. EU has regional development funds, possibly known as structured funds, having the second largest provision of budget [Dorantes and Wheeler, 2001].

It is economic reality that country's quantitative and qualitative polices directly impacts its GDP growth and development. Countries in Asia region encompass common characteristics that influence macro policy results, stability and choices. It is standard fact that countries with good economic conditions are operationally efficient. A survey of global financial and economic practices suggests that current economic conditions of Asian countries are not optimal. On the other hand, EU is a single largest market of the world with transparent rules and regulations and also secures the legal investment framework. EU trading bloc is now world largest exporter and importer to more than 85 countries around the globe. Know with modern transportation and communication, it is easier to produce, sell and buy products around the whole world.

EU trading bloc works for the members of European Union and is suggestion for Asian countries to construct the trading blocs for improved performance and better wellbeing of the people of entire region. If Asian countries construct the trading bloc like as EU member countries so Asian people will receive the following kinds of welfare benefits like as increased economies of scope and scale, market efficiency and competition, free trade within the bloc, international risk sharing, financial market integration, increased FDI, more jobs and protection. All these are possible through Silk Road Economic Belt routes in a better way.

\section{LITERATURE REVIEW}

The authors have critically reviewed some of the important empirical researches to develop main objectives in the environment of Asian countries and further to utilize it and to draw important conclusions and recommendations for policy making. Imran et al in 2015 investigated that economic parameters affects the economic growth and in turn economic growth can also be improved by such indicators like as Gross Capital Formation, Trade Openness and Foreign Direct Investment. Economic growth is also affected by structural changes and structural changes do not come without any cost. 
Positive economic changes are only possible when better economic policies are adopted. Strict government controls can never provide optimal level of welfare. Timothy in 2004 said that barriers include the political and geographical fragmentation. As European Union works together for setting policies for collective interest through common institutions. Imran in 2016 said that economic and trading bloc has ability to identify the issues and fill the gaps by increasing the production and welfare of the people. Imran in 2016 also finds that members of EU have experienced a large rise after the mid of $20^{\text {th }}$ century and still today. Whalley in 1996 have examined the various motives between the countries for constructing the regional free trading blocs/agreements. Kruegar in 1999 studied trade diversion and trade creation under NAFTA. Room in 2005 said the Libson process moves EU toward socially inclusive and dynamic economy. Lee and Mensbrugghe in 2009 explored the impacts for regional integration in North America, Asia and EU.

\section{Data Collection}

EU has 28 member countries while data is taken from only thirteen countries having membership before 1996 except Luxemburg (performing an outlier). From Asian countries only fifteen countries are selected by researcher's own interest. But the data on education for Asian countries is mainly missing for showing members countries performance regarding education. The data set consists of 20 years period from 1996 to 2015

\section{Data ANAlysis}

Basic purpose of data analysis is to check whether EU trading bloc have improved the performance of member countries or not? Data analysis is further divided into eight subsections which are presented below:

\section{A. Adjusted Net National Income (Fig. 1a \& Fig. 1b)}

Adjusted net national income adjusted for gross national income is showing some even patterns in Fig. 1a representing the EU trading bloc performance and growth ranges from -5 to 5.2 per cent. While Fig. 1b represents growth performance of selected Asian countries and showing even adjusted net national income growth in Asian countries is not showing uneven patterns with a lot of variation in growth ranges from 11 to 17 percent.

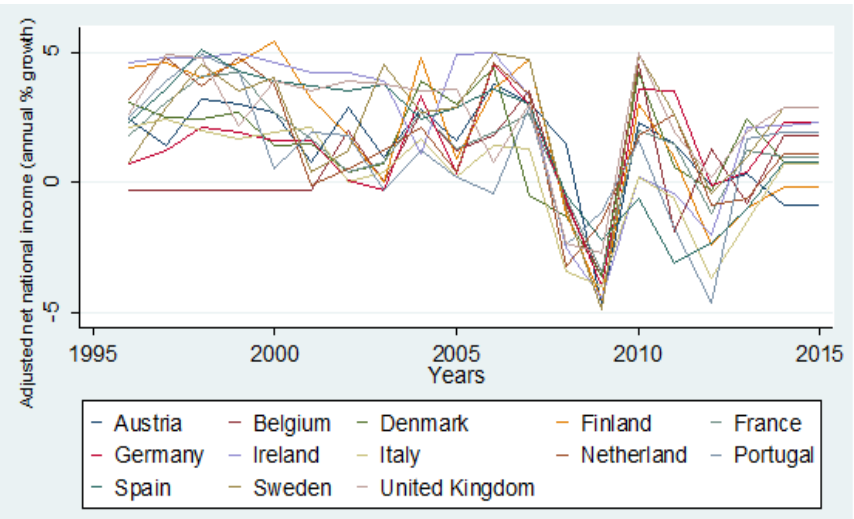

Fig. 1a. Adjusted net national income (annual \% growth)

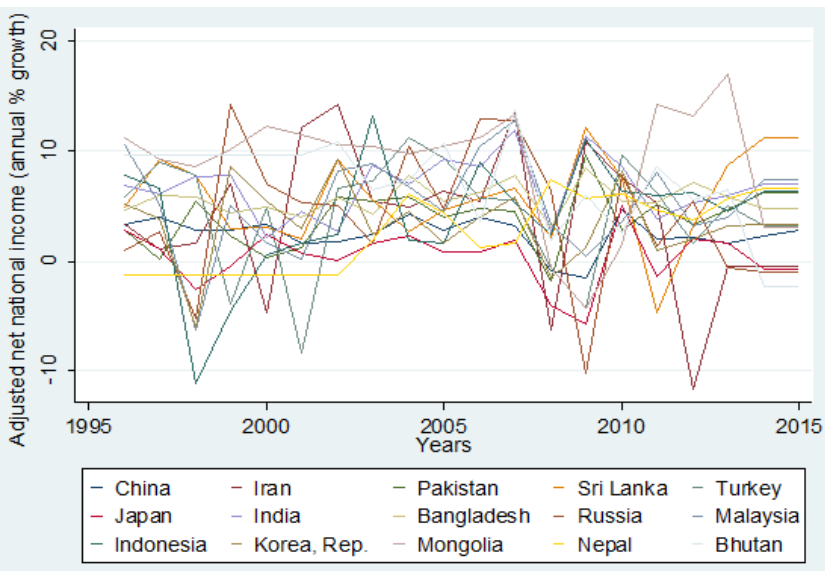

Fig. 1b. Adjusted net national income (annual \% growth)

\section{B. Exports of Goods and Services (Fig. 2a \& Fig. 2b)}

Export of goods and services with annual growth rate represents total market value of domestically produced goods and services. Fig. 2a shows EU member countries performance and is making band and ranges from -20 to 16 per cent while Fig. 2b shows uneven patterns in Asian countries.

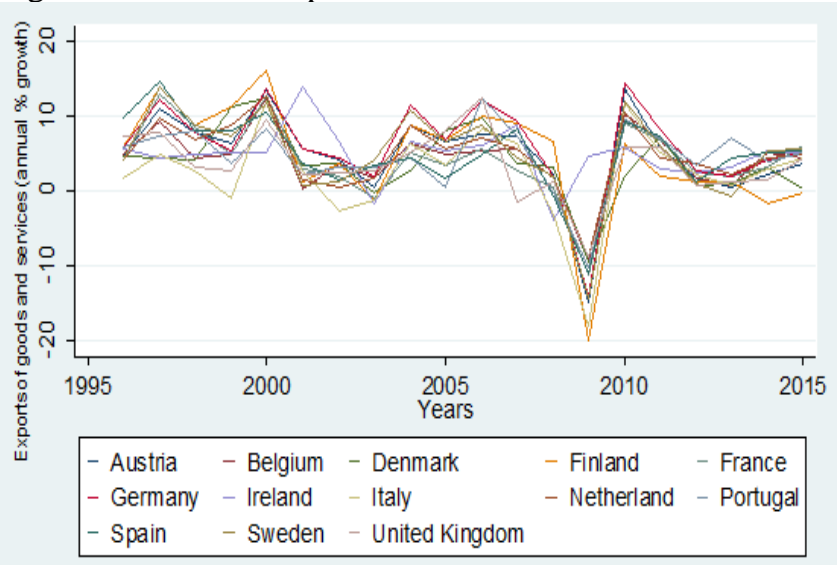

Fig. 2a. Exports of goods and services (annual \% growth)

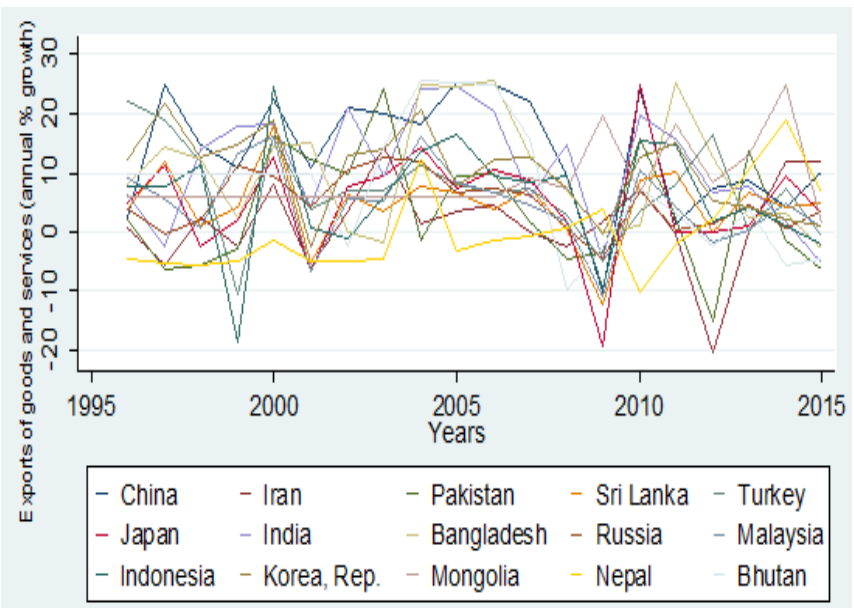

Fig. 2b. Exports of goods and services (annual \% growth) 
C. GDP Per Capita at Power Purchase Parity (Fig. 3a \& Fig. 3b)

GDP per capita is GDP divided by population (midyear). After the formation of EU trading bloc GDP per capita for member countries not only improved but moving forward with same pace and ranges from dollars 15000 to dollars 50000 are shown in Fig. 3a, while Fig. 3b for Asian countries is showing huge differences and GDP per capita is low even dollars 500 and only one country Japan is touching dollars 40000.

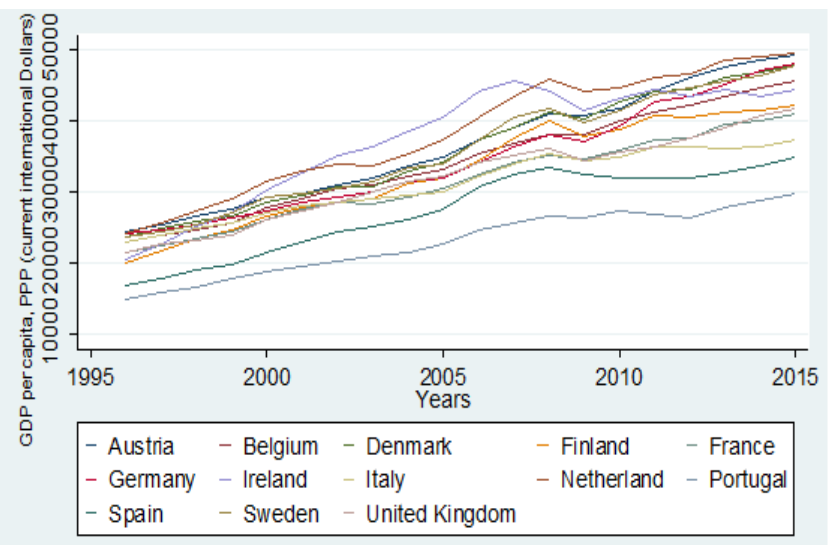

Fig. 3a. GDP per capita, PPP (current international dollars)

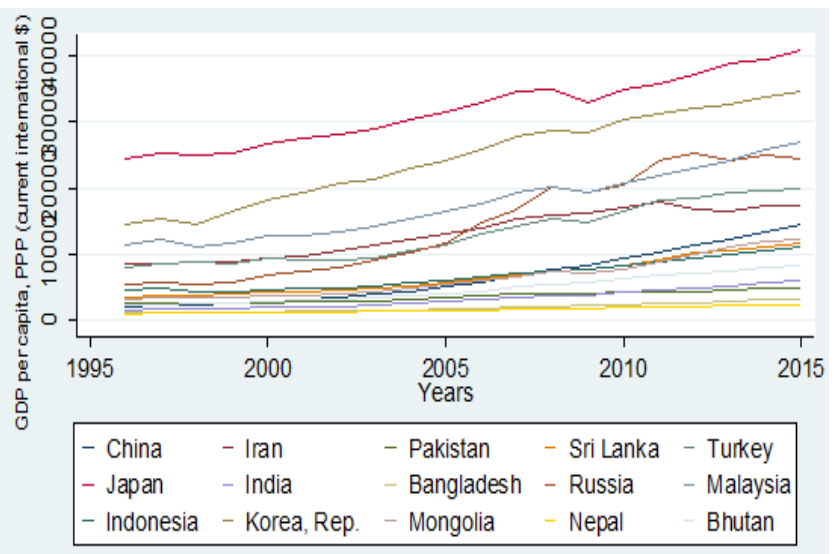

Fig. 3b. GDP per capita, PPP (current international dollars)

\section{Inflation at Consumer Price Index (Fig. 4a \& Fig. 4b)}

Inflation is measured through consumer price index that reflects the annual price percentage changes in consumers fixed basket of goods and services. Fig. 4a shows that EU member countries have ability to maintain inflation at low band from -2 to 5 which is good sign for stable economic framework. In Fig. 4b Asian countries are facing the inflation up to 29 per cent which is very high and others are also showing uneven patterns.

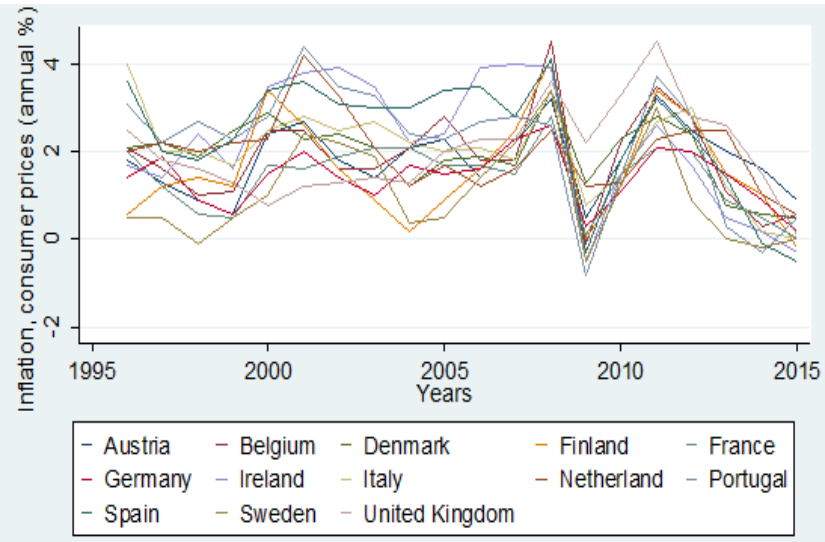

Fig. 4a. Inflation, consumer prices (annual \%)

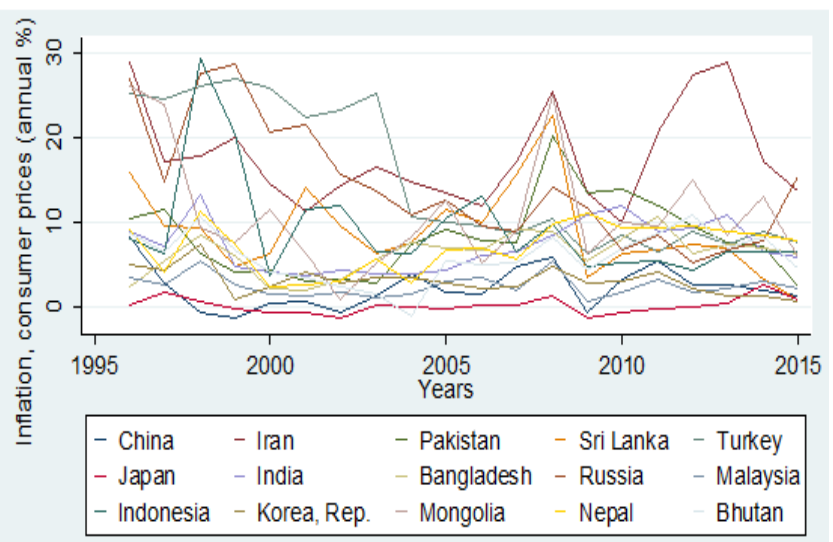

Fig. 4b. Inflation, consumer prices (annual \%)

\section{E. Internet Users per 100 people (Fig. 5 a \& Fig. 5b)}

Individuals those use internets via computer, mobile etc. from any location are included in internet users. Internet is a very big source of providing information. Fig. 5a shows number of internet users is increasing more rapidly in EU members when comparing with Asian countries as shown in Fig. 5b.

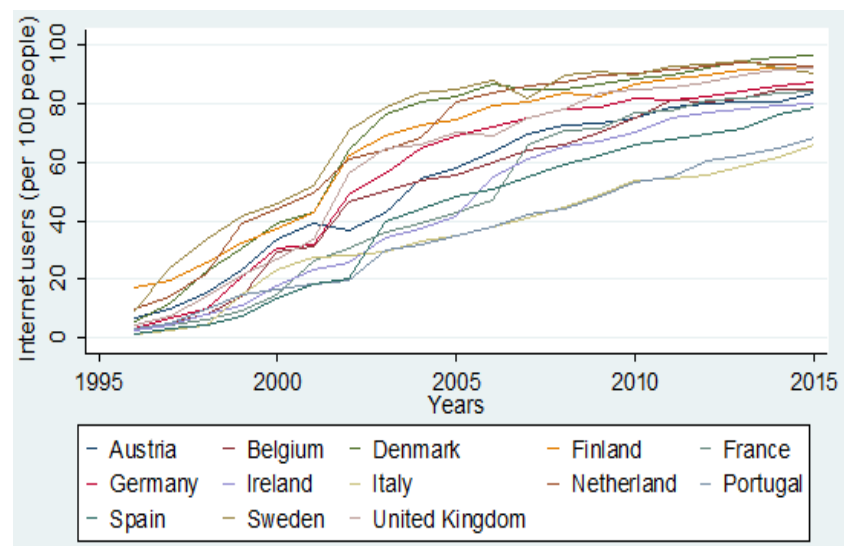

Fig. 5a. Internet users (per 100 people) 


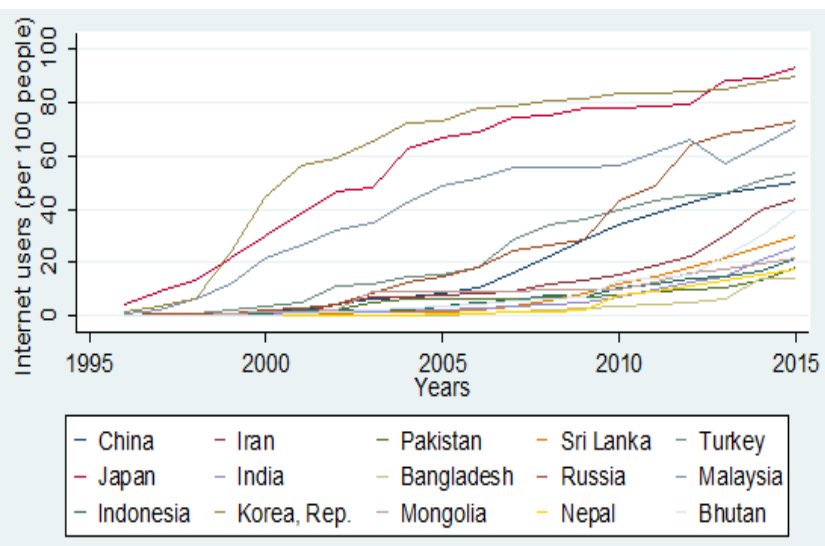

Fig. 5b. Internet users (per 100 people)

\section{F. Life Expectancy at Birth (Fig. 6a \& Fig. 6b)}

Life expectancy at birth indicated total years a newborn would live. Fig. 6a showing increased and even patterns for EU member countries for life expectancy at birth while Asian countries are not showing impressive positive change.

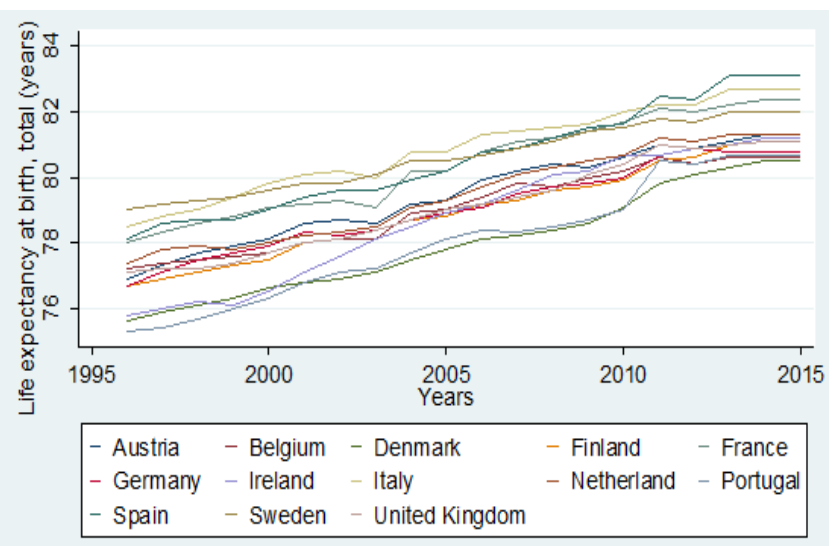

Fig. 6a. Life expectancy at birth, total (years)

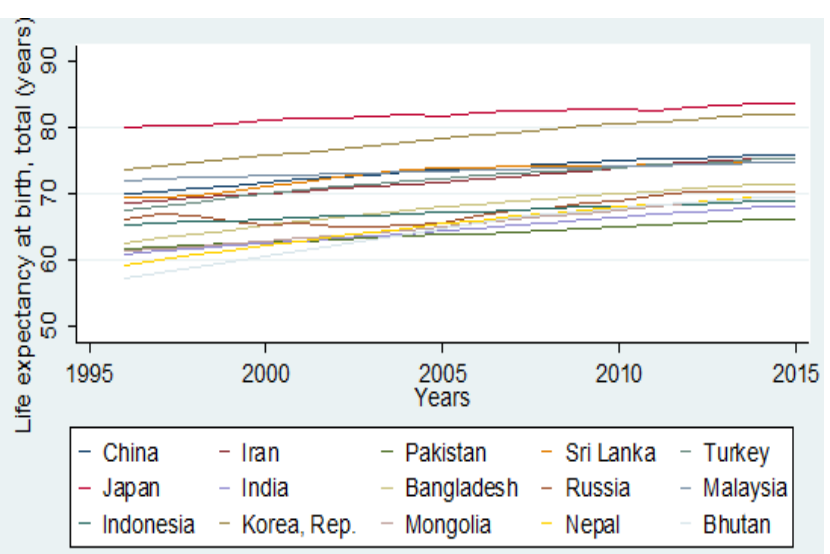

Fig. 6b. Life expectancy at birth, total (years)

\section{G. Military Expenditure (Fig. 7a \& Fig. 7b)}

Military expenditures include expenditures on armed force and other agencies of government engaged in projects of national defense. Fig. 7a showing that EU member countries are reducing their military expenditures which is good sing for positivity and no war while Fig. 7b shows many countries from
Asia are increasing their military expenditure/defense budget day by day, Pakistan and India are best examples. This is not good for economic growth and development.

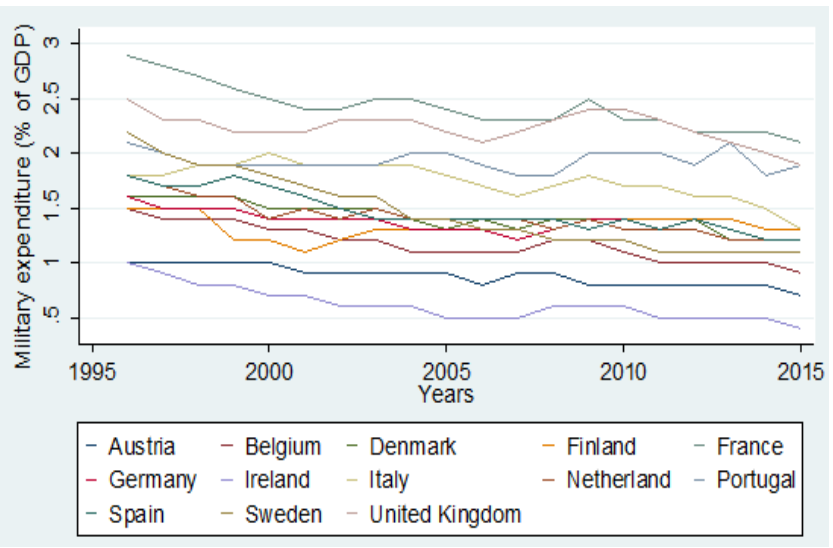

Fig. 7a. Military expenditure (\% of GDP)

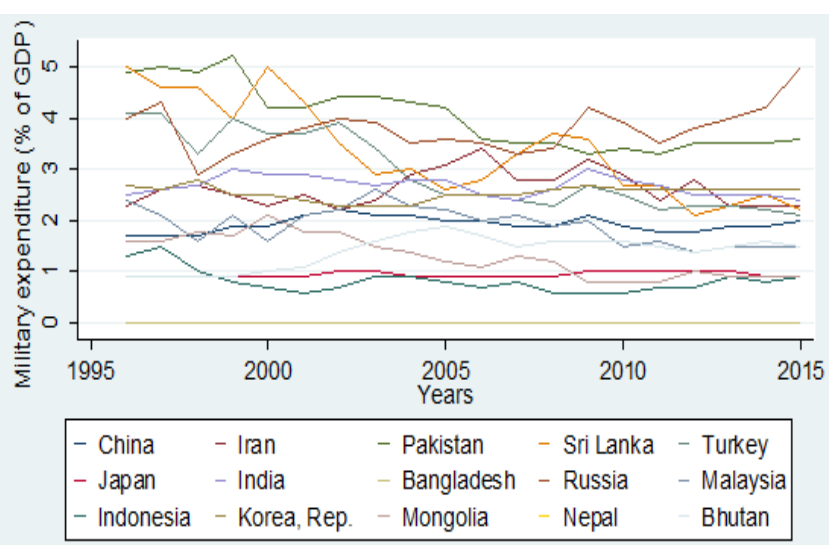

Fig. 7b. Military expenditure (\% of GDP)

\section{H. Unemployment Rate (Fig. 8a \& Fig. 8b)}

Unemployment refers to the labor force share without work but seeking/willing for employment. Fig. 8a shows unemployment rate is reducing in many EU member countries but some countries are showing odd pattern. While Fig. 8b shows that Asian countries still accounts high and persistent unemployment which is not good for sustainable economic growth and development.

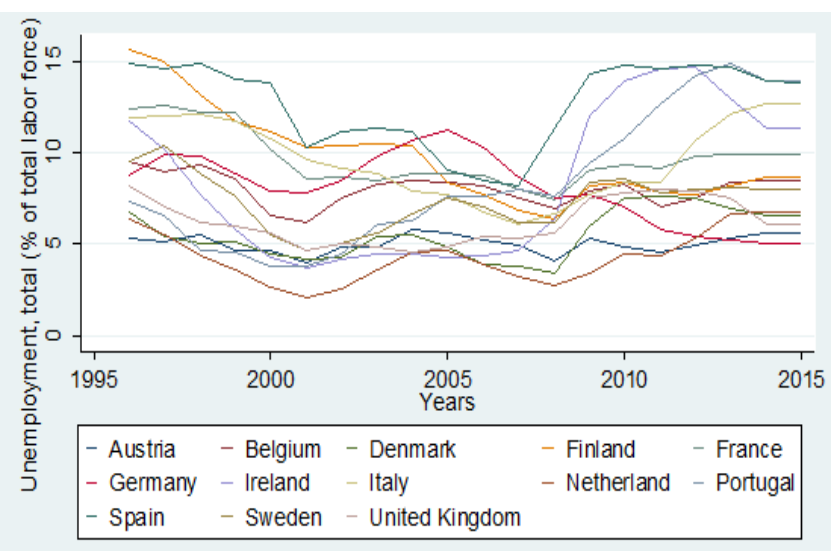

Fig. 8a. Unemployment, total (\% of total labor force) 




Fig. 8b. Unemployment, total (\% of total labor force)

\section{CONCLUSION}

EU trading bloc not only improves single country's performance but also increases the performance of the region. Hence trading refers regional growth and development. Trading bloc increases the co-operation among the member countries. After the increased performance of member countries in the European Union, here is a suggestion for Asian country to construct trading bloc. These trading blocs in near future will not improve the performance of member countries; it will also increase wellbeing of the people of whole Asian region.

\section{REFERENCES}

[1] Amuedo-Dorantes and Wheeler, M. (2001). An empirical analysis of the European Union's impact on Spanish economic performance. Applied Economics, 33 (8): 1001.

[2] Imran, M., Mughal, K. S., Salman, A., \& Makarevic, N. (2015). Unemployment and Economic Growth of Developing Asian Countries: A Panel Data Analysis. European Journal of Economic Studies, 13 (3), $147-160$.

[3] Imran, M. (2016). European Union Trading Bloc: Motivation for East Asian Countries. European Journal of Economic Studies, 15(1), 259266.

[4] International Labor Organization Press Report 2010.

[5] Krueger, A. (1999). Trade Creation and Trade Diversion under the NAFTA, NBER Working Paper, Number 7429.

[6] Lee H., and Mensbrugghe, D. (2009). Regional Integration in Asia and its Effects on the EU and North America, Journal of Asian Economics, 20, pp.240-254.

[7] Room, G. (2005). Policy Benchmarking in the European Union: Indicators and Ambiguities. Policy Studies, 26 (2): 117.

[8] Timothy, D. J. (2001). Touris $m$ and Political Boundaries. Rout ledge: London.

[9] Whalley, J. (1996). Why do Countries Seek Regional Trade Agreements, NBER Working Paper, Number 5552. 